\title{
Measuring Transport Time of Mine Equipment in an Underground Mine Using a Bluetooth Beacon System
}

\author{
Jihoo Jung and Yosoon Choi * \\ Department of Energy Resources Engineering, Pukyong National University, Busan 608-737, Korea; \\ haksu8874@gmail.com \\ * Correspondence: yspower7@gmail.com or energy@pknu.ac.kr; Tel.: +82-51-629-6562; Fax: +82-51-629-6553 \\ Academic Editors: Saiied Aminossadati and Paul Sylvester \\ Received: 27 October 2016; Accepted: 20 December 2016; Published: 23 December 2016
}

\begin{abstract}
In this study, the time taken for mine haulage equipment to travel between destinations in an underground mine was measured and analyzed using a Bluetooth beacon system. In this system, Bluetooth beacons are attached to multiple points in an underground mine environment, and smartphones are mounted on mine equipment, such as haulage trucks, to collect transport time data. An underground limestone mine in Korea was selected to test the Bluetooth beacon system. The field experiments indicated that smartphones mounted on haulage trucks can recognize all Bluetooth beacons installed in the vicinity. The results also revealed that the Bluetooth beacon system can be used successfully in underground mines to quantitatively analyze transport times of haulage trucks going back and forth between loading and dumping points.
\end{abstract}

Keywords: Bluetooth beacon system; transport time; underground mine; time study

\section{Introduction}

The cost of haulage operations in mines is on the rise due to the longer haul routes and higher fuel consumption necessitated by deepening mines [1,2]. Accordingly, designing an efficient haulage system for ores and wastes is crucial when planning open-pit or underground mines [3-8]. Various techniques have been developed to date by many researchers to optimize the haulage system which form a considerable part of mining costs [1,9-17]. For instance, Erelebi and Bascetin [12] analyzed the rate of operation in terms of loading equipment, ore yield, and rate of return based on the transporting equipment, and proposed a model to optimize the number and combination of the equipment deployed. Salama and Greberg [13] simulated a loading-haulage system to optimize the number of trucks used in an underground mine, and proposed a system operation plan to improve the efficiency of the haulage system. Park and Choi [1] used the transport times of equipment measured at actual mining sites to develop an underground mine conveyance simulation program that could compute the optimal numbers of equipment to be deployed on sites for one-day production output.

Past studies have generally used transport times of mine equipment to optimize their combinations, work orders, dispatching methods, and travel routes [7]. However, the reported accuracy of the measured transport time has been low because they mainly used stopwatches to measure these times. Moreover, collecting transport times of mine equipment using stopwatches is time consuming and tedious, especially for large underground mines. Although the stopwatch has been made to collect transport times of mine equipment as input data for optimizing the haulage system in mines, its relatively low accuracy and inefficiency still makes it difficult to generate mine production schedules of high quality. Therefore, a better method is required to measure the transport times of mine equipment. Against this background, this study proposes a method to effectively measure the transport times of mining equipment by using a Bluetooth beacon system, an Information and Communication Technology (ICT) recently introduced to various fields. 
Bluetooth technology was developed to implement two-way wireless communication between mobile devices. Its initial release in 2001 has been followed by continual development to reduce power consumption and improve data transmission speed. In 2010, Bluetooth 4.0 (Bluetooth Low Energy, BLE) was released, with a reduction in power consumption of up to $90 \%$ over its predecessor. BLE technology was designed to implement the Internet of Things (IoT), and a representative BLE-based product, Bluetooth beacon, is now being used in a variety of industries for such purposes as indoor positioning services, surrounding change perception, and location-based services [18]. A Bluetooth beacon is a device that periodically transfers wireless signals, including location information, and sends user IDs and received signal strength indication (RSSI) as Bluetooth signals. When a smartphone user is within its signal range, the relevant smartphone application receives a beacon signal and transmits the user information to a cloud server. The cloud server identifies the user information and sends the related service information to the user [19].

A Bluetooth beacon-based service can be implemented in various formats depending on application development methods, and many researchers have studied methods to effectively use Bluetooth beacons in different fields. For example, Ha et al. [20] created a user-centered platform that can help easily develop a beacon-exclusive application on Windows, and Jin et al. [21] created a Bluetooth beacon-based factory patrol service using this platform. When a patroller carrying a beacon passes a spot where a Bluetooth receiver is installed, his/her manager can track the real-time movement of the patroller. Bae and Cho [22] developed a beacon-based automatic attendance tracking system; when a student with a mobile beacon application entered a beacon-equipped classroom, the attendance status was updated based on location information from the student's smartphone. Yoon and Hwang [23] revised the values of irregular receipt signals of the beacon signal RSSI using the Kalman filter and a genetic operation method, thus offering a beacon-based indoor positioning service at high precision. Although the range of application of Bluetooth beacon-based services is increasing, few studies have tackled the measurement of transport times of mining equipment in underground mines using a Bluetooth beacon system.

The purpose of this study is to quantitatively measure the transport time of equipment used in real underground mines by using a Bluetooth beacon system. We selected a Korean underground limestone mine as our research case study, and installed Bluetooth beacons in the main locations of the underground mine. We also measured the travel time of dump trucks with a loading capacity of 15 tons used in ore transportation work, by equipping smartphones that can recognize beacon signals. We then quantitatively analyzed the time taken in the conveyance work based on data concerning the movement of the dump truck gathered by the Bluetooth beacon system.

\section{Study Area}

We chose a limestone mine located in Daepyeong-ri, Shinki-myeon, Samcheok-si, Gangwon-do, South Korea as our research case study (Figure 1). A large amount of high-grade limestone is buried in this mine, which is operated by Daesung Mining Development Inc. (Seoul, Korea). The limestone generated here is mainly used to manufacture steel and high-quality cement due to its excellent durability, strength, and uniformity. Approximately 1.5 million tons of limestone ore is mined annually on average. 


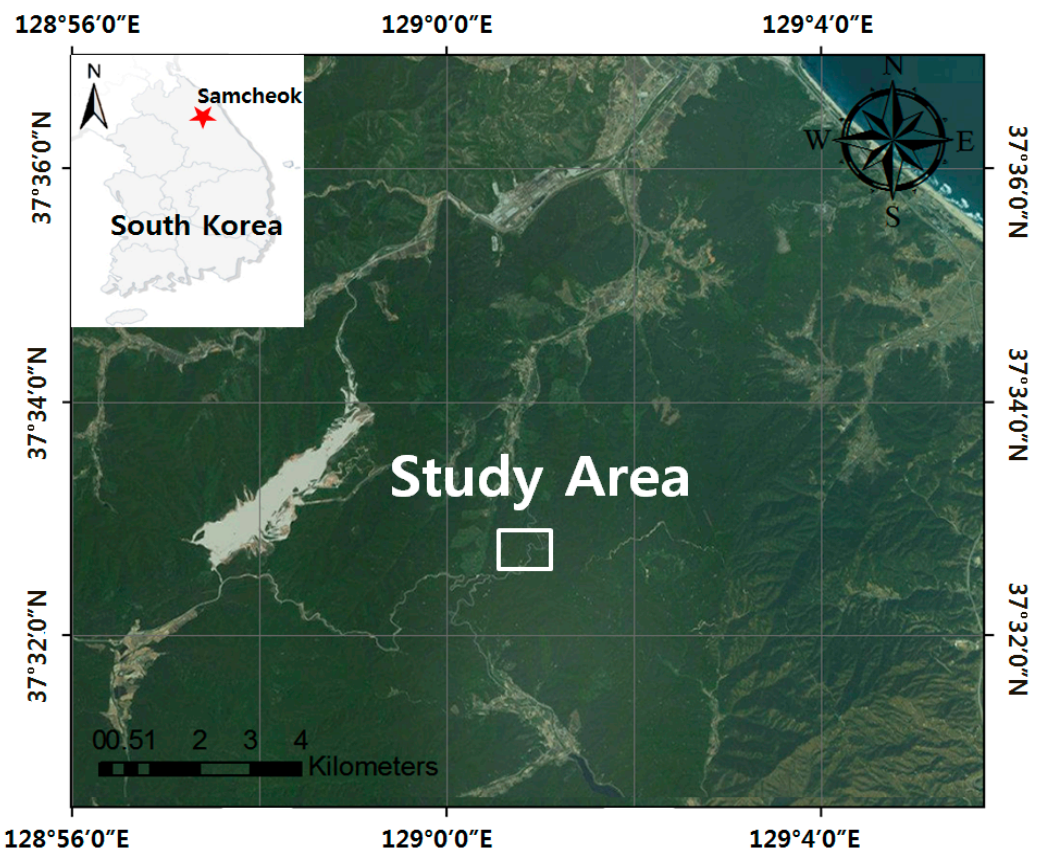

Figure 1. Aerial view of the study area (Daesung Mining Development Inc. (MDI) underground limestone mine), Samcheok-si, Gangwon-do, Korea [24].

The limestone ore mined in the pit is loaded into dump trucks, moved to a crushing head located outside the underground mine, and released as complete product after dressing procedures. Ore was mined at three loading points in the underground mine, and loaders and dump trucks were assigned to the loading points according to their daily production schedules (Figure 2). The dump trucks deployed to each loading point transport ore while going back and forth between the assigned loading point and crushing head during operation. Some waiting time is incurred for trucks at the loading point and the crushing head. Moreover, when trucks on the way to the loading point after unloading ore encounter others heading for the crushing head along the narrow haulage road, they yield by stopping in certain spots to avoid an impasse. This also contributes to the waiting time.

In this study, we installed Bluetooth beacons at the main locations of our study area in order to measure the transport times of equipment in underground mines by using a Bluetooth beacon system using 15-ton dump trucks, and quantitatively measured the moving times of the trucks going back and forth between the loading point and the crushing head with a smartphone that can recognize beacon signals.

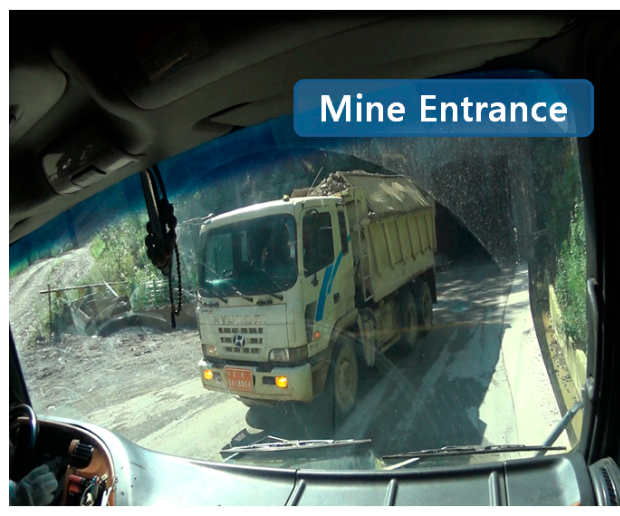

(a)

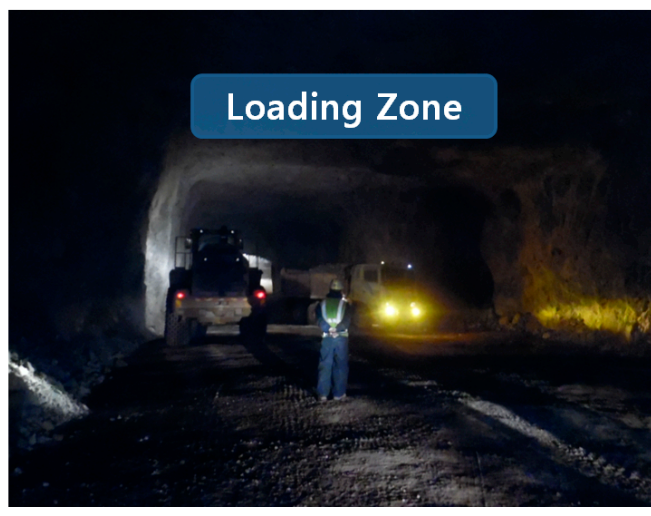

(b)

Figure 2. Views of the Daesung MDI underground limestone mine. (a) Mine entrance; (b) Loading zone. 


\section{Research Method}

\subsection{Research Equipment}

We used a RECO beacon (Perples, Seoul, Korea) and a Samsung Galaxy Note 3 smartphone (Samsung, Seoul, Korea) in this research to organize a Bluetooth beacon system (Figure 3a,b). The RECO beacon satisfies and supports the standards of both the iBeacon of Apple and Eddystone of Google, which are the worldwide standards of Bluetooth beacons. Both have been certified by many international organizations, such as the Federal Communication Commission (FCC), Conformité Européenne (CE) marking, Korea Certification (KC), and the Technical Regulations Conformity Certification (TELEC). A beacon ID can be entered through an administrator application offered by Perples, and the signal transmission period can be configured between 0.01 and $2 \mathrm{~s}$. Moreover, the Bluetooth signal strength ( $\mathrm{tx}$ power) can be set between -16 and $4 \mathrm{dBm}$. The RECO beacon is simple to install because it is small and light, and its case has strong durability as it is made from Acrylonitrile Butadiene Styrene (ABS) plastic. Moreover, since it is waterproof and dustproof, it is appropriate for use in extreme conditions, such as in a mine. The Galaxy Note 3, used as our Bluetooth beacon receiving apparatus, has a built-in Bluetooth module that supports Bluetooth Version 4.0, and has a 3200-mAh battery (Youngbo Chemical, Cheongju, Korea). It runs on Android Version 4.3 (Google, Menlo Park, CA, USA). The detailed specifications of the equipment used in this study are presented in Table 1. Because this system complies with KC and TELEC, it can be used in underground mines producing not only limestone but also other minerals, including coal.

Table 1. Specifications of the RECO beacon (Perples, Seoul, Korea) and Galaxy Note 3 (Samsung, Seoul, Korea).

\begin{tabular}{|c|c|}
\hline Model & Properties \\
\hline RECO beacon & $\begin{array}{l}\text { Size }(\text { diameter } \times \text { height): } 45 \mathrm{~mm} \times 20 \mathrm{~mm} \\
\text { Weight: } 11.6 \mathrm{~g} \\
\text { Processor: } 32 \text {-bit ARM }{ }^{\circledR} \text { Corte }{ }^{\circledR}-\mathrm{M} 0 \text { (ARM Holdings, Cambridge, UK) } \\
\text { Battery: CR2450 lithium-ion battery ( } 3 \mathrm{~V}, 620 \mathrm{mAh} \text {, Avg. } 2 \text { year, Panasonic, Osaka, Japan) } \\
\text { Case: Acrylonitrile Butadiene Styrene (ABS) plastic } \\
\text { Heat-resistant property: } 93^{\circ} \mathrm{C}\left(200^{\circ} \mathrm{F}\right) \\
\text { Impact resistance: } 4.5 \\
\text { Water-resistant, Dustproof } \\
\text { Radio techniques: Bluetooth } 4.0 \text { (i.e., Bluetooth Low Energy (BLE) or Bluetooth }{ }^{\circledR} \text { Smart) } \\
\text { Chipset: Nordic nrf51822 (Nordic, Oslo, Norway) } \\
\text { Recognition range: } 1-70 \mathrm{~m} \\
\text { Power output: } 0.025-2.5 \mathrm{~mW}\end{array}$ \\
\hline $\begin{array}{l}\text { Galaxy Note } 3 \\
\text { (SM-N900) }\end{array}$ & $\begin{array}{l}\text { Application processor: Snapdragon } 800 \text { ( } 2.3 \mathrm{GHz} \text { quad-core, Qualcomm, San Diego, CA, USA) } \\
\text { Operating system: Android } 4.3 \text { (Google, Menlo Park, CA, USA) } \\
\text { Display: 5.7inch Super AMOLED (Samsung, Seoul, Korea) } \\
\text { RAM: } 3 \text { GB } \\
\text { Battery: } 3200 \text { mAh (Youngbo Chemical, Cheongju, Korea) } \\
\text { Bluetooth: Bluetooth v4.0 } \\
\text { Power output: } 0.56 \mathrm{~W}\end{array}$ \\
\hline
\end{tabular}




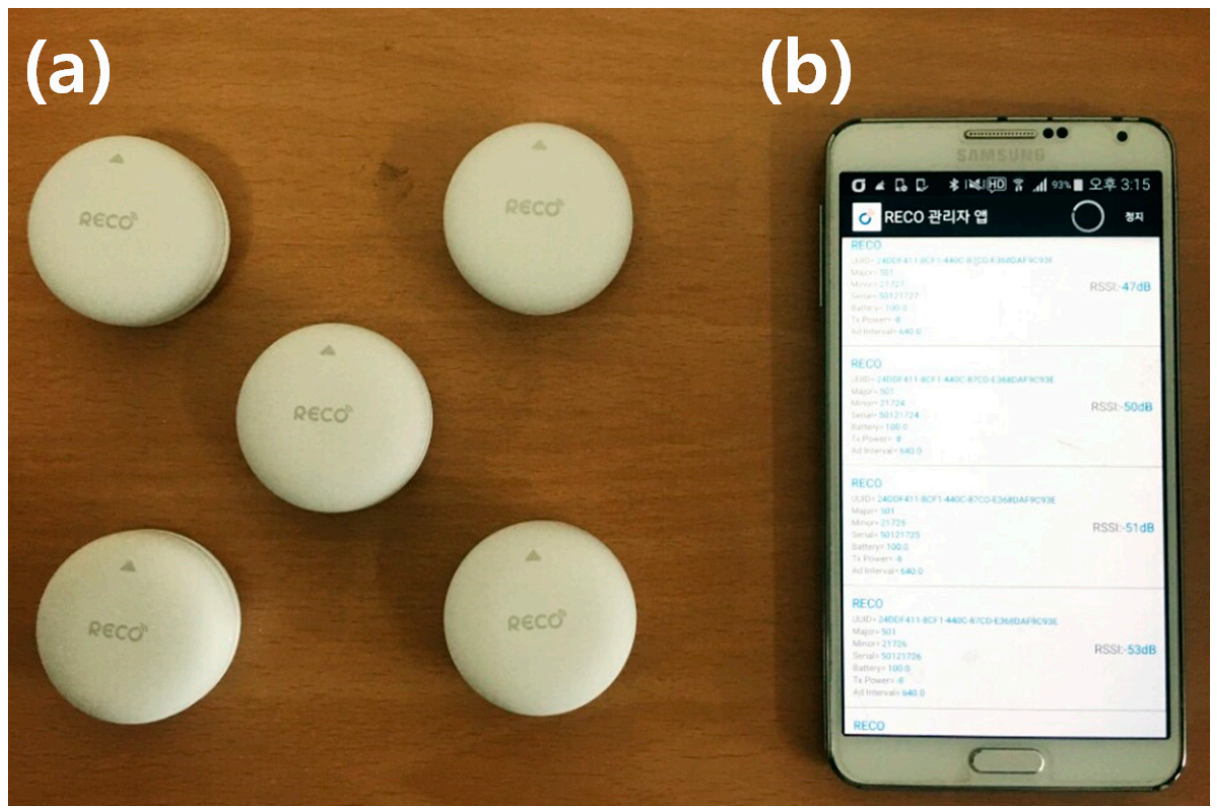

Figure 3. Views of the (a) RECO beacon (Perples, Seoul, Korea), (b) Galaxy Note 3 smartphone (Samsung, Seoul, Korea) used in this study.

\subsection{Experimental Method}

In a Bluetooth beacon system, the performance of the sensor varies according to device configuration. The configurable items in the Bluetooth beacon system used in this research are Bluetooth signal strength and signal transmission period. The higher the signal strength, the higher the recognition rate as the signal arrival range increases; however, there is also a high likelihood of a greater error in the measured data. The shorter the configured signal transmission period, the higher the possibility that a fast-moving object can be detected. At the same time, the power consumption of the device increases. Therefore, it is necessary to choose the system configuration according to each applied scenario; in the case of this study, it was necessary to raise the recognition rate by setting consecutive signals as wide apart as possible because the transport times for fast-moving equipment needed to be measured in the extreme conditions of an underground mine, with limitations on radio communication. Thus, Bluetooth signal strength was set at its maximum value (tx power: $4 \mathrm{dBm}$ ) and the signal transmission period was set to 10 times per second on average. Further, we assigned different IDs to beacons installed at the main spots of our research area in order to distinguish them.

In the research area, a dump truck passed the mine entrance and an intersection in the mine, stopped at the loading point to load ore, and passed the intersection and the mine entrance once again to head for the crushing head located outside the mine. This course was repeated. We installed five beacons, B1 to B5, within the operating route from the crushing head to the mine entrance, and seven beacons, B6 to B12, within the underground operating route from the mine entrance to the loading zone (Figure 4). The smartphone that detected Bluetooth beacon signals was installed in the passenger seat of the 15-ton dump truck. An app in the smartphone recorded beacon IDs and signal detection times. Thus, when the smartphone recognized a signal from each beacon, its ID and signal detection time were recorded; hence, travel time of the dump truck for each section could be quantitatively measured.

On the day of our experiment, we measured four round-trip operation times in total during the afternoon. The four round-trip operations were enough to simply check whether the Bluetooth beacon system can quantitatively analyze transport times of haulage trucks going back and forth between loading and dumping points or not. The dump truck moved slower than $30 \mathrm{~km} / \mathrm{h}$ on average per mine regulations. The main spots and the detailed locations of the beacons installed in the mine are shown in Figure 5. In this study, we set the time when the truck left the crushing head, where beacon 
B1 was installed, as our starting point, and the instance when ore is loaded on it for it to return to the crushing head as our end point. A single operation was set as the route where the dump truck left the crushing head, was loaded with ore, and returned to the crushing head. Therefore, when a truck moved to the loading point as an empty vehicle, the beacons were recognized in order from B1 to B12; when it was loaded with ore and returned to the crushing head, the beacons were recognized in order from B12 to B1. When the dump truck, equipped with the smartphone, entered the beacon signal arrival range, the beacon recognition times were consecutively recorded. The middle values of the first and last beacon recognition times, when the dump truck passed each spot where a beacon was installed, were selected as beacon recognition times.

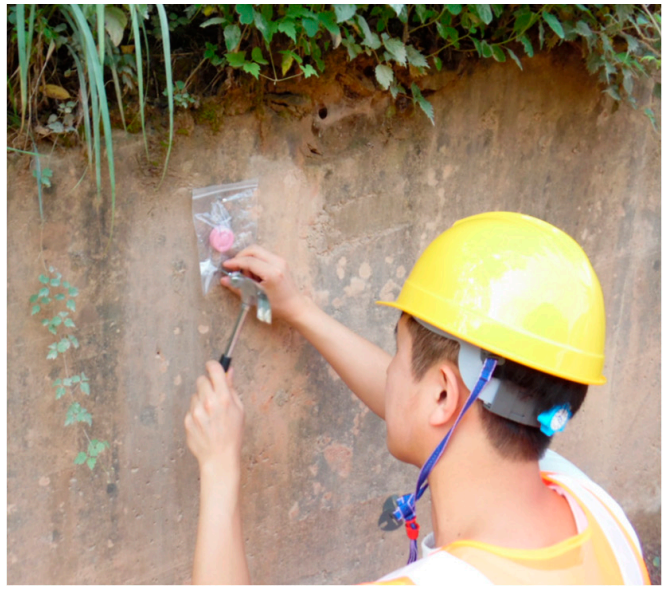

(a)

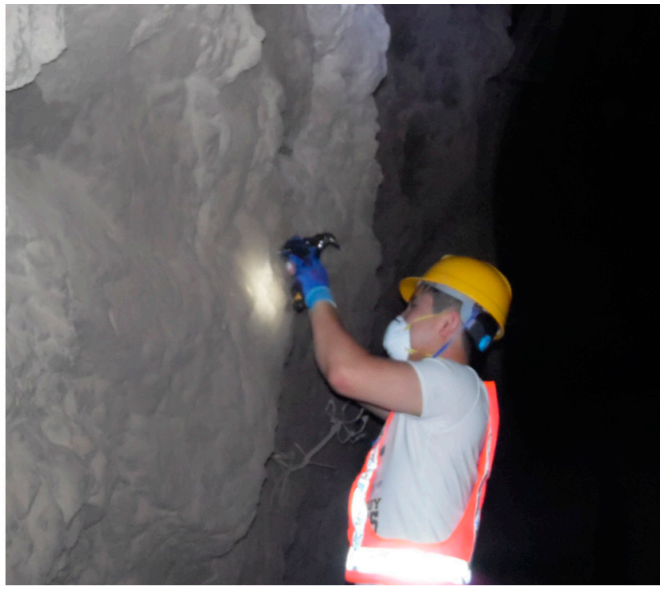

(b)

Figure 4. Views of Bluetooth beacons installed in study area. (a) Operating route; (b) Underground operating route.

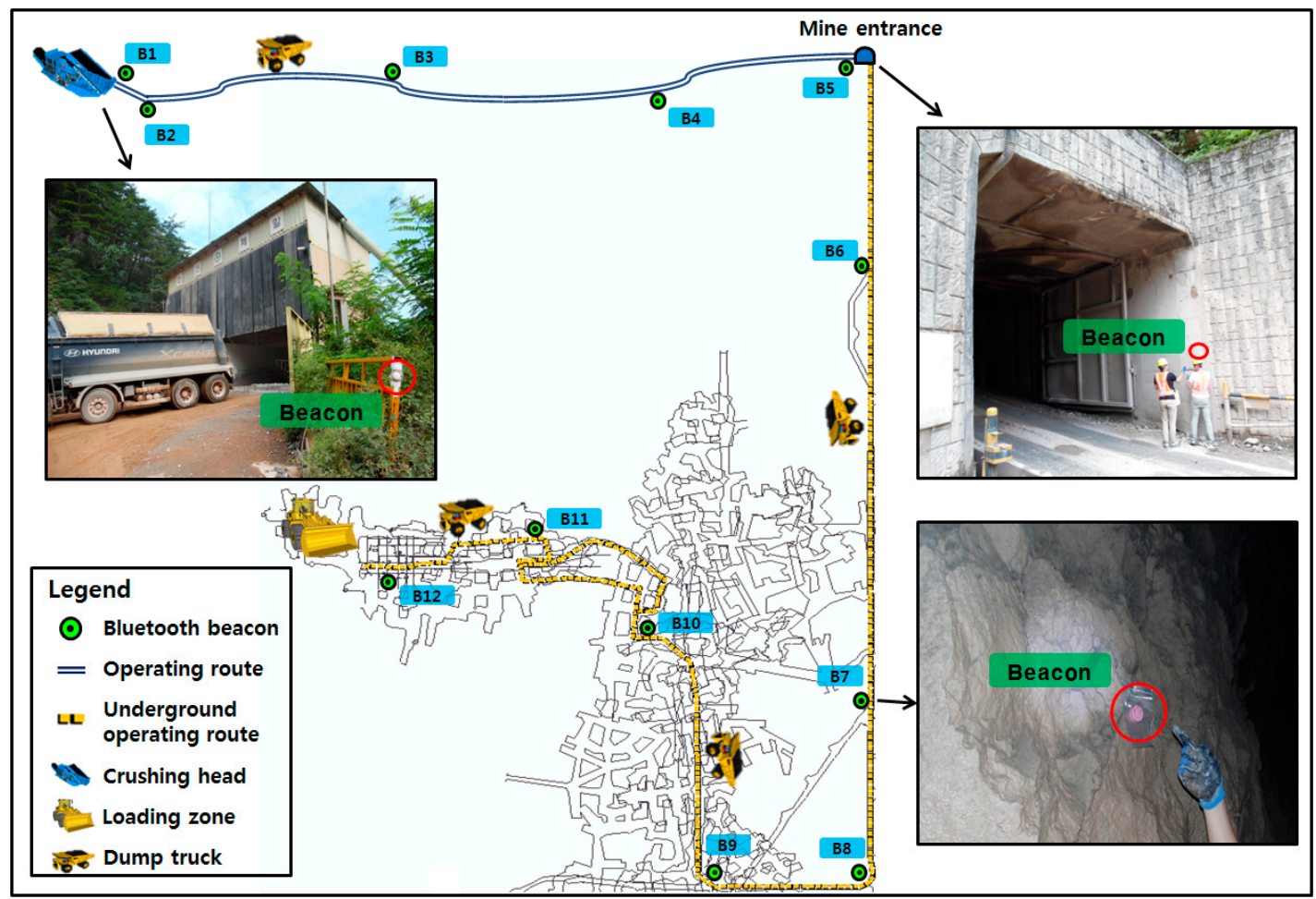

Figure 5. Mine map showing the positions of Bluetooth beacons installed in the study area. 


\section{Results and Discussion}

Table 2 lists the times measured when the dump truck passed the locations where the beacons were installed and the total transport time needed for one operation. C in Table 2 implies the crushing head, where mined ore was unloaded, and L implies the site where the ore was loaded onto the dump truck. Table 2 shows the calculated intermediate values of the first and last beacon recognition times on the smartphone. We did not list the recognition rates separately as they were $100 \%$ without fail in every trial.

Beacon B1 was recognized as the empty (unloaded) dump truck that left the crushing head in the first drive at 13:01:32. Beacon B5 detected the truck passing the mine entrance, after having been detected by ground driving sections B2, B3, and B4, at 13:5:11; the time taken on the ground was approximately $3 \mathrm{~min}$ and $39 \mathrm{~s}$, the time difference in recognition between beacon B1 and B5. The dump truck entered the mine and passed the loading zone, where beacon B12 was installed, at 13:15:17; it was recorded as leaving the loading point at 13:25:55. Thus, 10 min and $38 \mathrm{~s}$, between the time when the truck entered and left the loading zone, was the time taken to load ore onto the dump truck. The ore-loaded dump truck passed the mine entrance after passing the underground mine route at 13:40:59, and arrived at the crushing head at 13:48:02. The time spent by the truck in its first operation was the difference between the detection of the empty truck by beacon B1 while leaving the crushing head (13:01:32) and the detection of the loaded truck by the same beacon while it headed for the crushing head again (13:48:02). This was $46 \mathrm{~min}$ and $29 \mathrm{~s}$, approximately.

The times recorded for the next three operations can be seen in Table 2. The time spent for each of the remaining iterations was $36 \mathrm{~min}$ and $52 \mathrm{~s}$ (second operation), $40 \mathrm{~min}$ and $36 \mathrm{~s}$ (third operation), and $35 \mathrm{~min}$ and $23 \mathrm{~s}$ (fourth operation), respectively. We can see that the operating times for the first and third iterations were longer than those of the second and fourth. This was because the operation at the loading point where beacon B12 was installed took longer.

Table 2. Field experimental data measured by the Bluetooth beacon system in the study area.

\begin{tabular}{|c|c|c|c|c|c|c|c|c|c|}
\hline $\begin{array}{c}\text { Beacon } \\
\left({ }^{*} \mathrm{C} \rightarrow{ }^{*} \mathrm{~L}\right)\end{array}$ & 1st & 2nd & 3 rd & 4th & $\begin{array}{l}\text { Beacon } \\
(\mathrm{L} \rightarrow \mathrm{C})\end{array}$ & 1st & 2nd & 3 rd & 4th \\
\hline B1 & $\begin{array}{c}\text { 13:01:32.3 } \\
\text { PM }\end{array}$ & $\begin{array}{c}\text { 13:49:58.8 } \\
\text { PM }\end{array}$ & $\begin{array}{c}\text { 14:28:40.5 } \\
\text { PM }\end{array}$ & $\begin{array}{c}\text { 15:14:40.6 } \\
\text { PM }\end{array}$ & B12 & $\begin{array}{c}\text { 13:25:54.9 } \\
\text { PM }\end{array}$ & $\begin{array}{c}\text { 14:07:54.2 } \\
\text { PM }\end{array}$ & $\begin{array}{c}\text { 14:51:24.1 } \\
\text { PM }\end{array}$ & $\begin{array}{c}\text { 15:33:53.1 } \\
\text { PM }\end{array}$ \\
\hline B2 & $\begin{array}{c}\text { 13:01:43.6 } \\
\text { PM }\end{array}$ & $\begin{array}{c}\text { 13:50:14.0 } \\
\text { PM }\end{array}$ & $\begin{array}{c}\text { 14:28:52.3 } \\
\text { PM }\end{array}$ & $\begin{array}{c}\text { 15:14:51.2 } \\
\text { PM }\end{array}$ & B11 & $\begin{array}{c}\text { 13:27:42.7 } \\
\text { PM }\end{array}$ & $\begin{array}{c}\text { 14:08:31.8 } \\
\text { PM }\end{array}$ & $\begin{array}{c}\text { 14:52:02.7 } \\
\text { PM }\end{array}$ & $\begin{array}{c}\text { 15:34:21.8 } \\
\text { PM }\end{array}$ \\
\hline B3 & $\begin{array}{c}\text { 13:03:27.5 } \\
\text { PM }\end{array}$ & $\begin{array}{c}\text { 13:51:26.4 } \\
\text { PM }\end{array}$ & $\begin{array}{c}\text { 14:30:24.9 } \\
\text { PM }\end{array}$ & $\begin{array}{c}\text { 15:15:45.6 } \\
\text { PM }\end{array}$ & B10 & $\begin{array}{c}\text { 13:29:56.2 } \\
\text { PM }\end{array}$ & $\begin{array}{c}\text { 14:10:16.4 } \\
\text { PM }\end{array}$ & $\begin{array}{c}\text { 14:53:36.0 } \\
\text { PM }\end{array}$ & $\begin{array}{c}\text { 15:35:55.4 } \\
\text { PM }\end{array}$ \\
\hline B4 & $\begin{array}{c}\text { 13:05:11.7 } \\
\text { PM }\end{array}$ & $\begin{array}{c}\text { 13:52:48.7 } \\
\text { PM }\end{array}$ & $\begin{array}{c}\text { 14:31:41.2 } \\
\text { PM }\end{array}$ & $\begin{array}{c}\text { 15:17:02.8 } \\
\text { PM }\end{array}$ & B9 & $\begin{array}{c}\text { 13:31:30.1 } \\
\text { PM }\end{array}$ & $\begin{array}{c}\text { 14:11:43.9 } \\
\text { PM }\end{array}$ & $\begin{array}{c}\text { 14:55:17.7 } \\
\text { PM }\end{array}$ & $\begin{array}{c}\text { 15:37:13.3 } \\
\text { PM }\end{array}$ \\
\hline B5 & $\begin{array}{c}\text { 13:05:52.1 } \\
\text { PM }\end{array}$ & $\begin{array}{c}\text { 13:53:11.1 } \\
\text { PM }\end{array}$ & $\begin{array}{c}\text { 14:32:16.7 } \\
\text { PM }\end{array}$ & $\begin{array}{c}\text { 15:17:52.2 } \\
\text { PM }\end{array}$ & B8 & $\begin{array}{c}\text { 13:32:29.9 } \\
\text { PM }\end{array}$ & $\begin{array}{c}\text { 14:12:38.1 } \\
\text { PM }\end{array}$ & $\begin{array}{c}\text { 14:56:14.0 } \\
\text { PM }\end{array}$ & $\begin{array}{c}\text { 15:38:08.7 } \\
\text { PM }\end{array}$ \\
\hline B6 & $\begin{array}{c}\text { 13:08:27.2 } \\
\text { PM }\end{array}$ & $\begin{array}{c}13: 55: 29.3 \\
\text { PM }\end{array}$ & $\begin{array}{c}\text { 14:34:44.0 } \\
\text { PM }\end{array}$ & $\begin{array}{c}\text { 15:20:09.0 } \\
\text { PM }\end{array}$ & B7 & $\begin{array}{c}\text { 13:33:35.6 } \\
\text { PM }\end{array}$ & $\begin{array}{c}\text { 14:13:50.9 } \\
\text { PM }\end{array}$ & $\begin{array}{c}\text { 14:57:16.3 } \\
\text { PM }\end{array}$ & $\begin{array}{c}\text { 15:39:10.1 } \\
\text { PM }\end{array}$ \\
\hline B7 & $\begin{array}{c}\text { 13:10:01.9 } \\
\text { PM }\end{array}$ & $\begin{array}{c}\text { 13:57:11.3 } \\
\text { PM }\end{array}$ & $\begin{array}{c}\text { 14:36:27.7 } \\
\text { PM }\end{array}$ & $\begin{array}{c}\text { 15:21:48.6 } \\
\text { PM }\end{array}$ & B6 & $\begin{array}{c}\text { 13:36:28.5 } \\
\text { PM }\end{array}$ & $\begin{array}{c}\text { 14:16:35.5 } \\
\text { PM }\end{array}$ & $\begin{array}{c}\text { 15:00:10.8 } \\
\text { PM }\end{array}$ & $\begin{array}{c}\text { 15:41:32.8 } \\
\text { PM }\end{array}$ \\
\hline B8 & $\begin{array}{c}\text { 13:10:41.8 } \\
\text { PM }\end{array}$ & $\begin{array}{c}\text { 13:57:49.9 } \\
\text { PM }\end{array}$ & $\begin{array}{c}\text { 14:37:05.2 } \\
\text { PM }\end{array}$ & $\begin{array}{c}\text { 15:22:24.4 } \\
\text { PM }\end{array}$ & B5 & $\begin{array}{c}\text { 13:40:59.3 } \\
\text { PM }\end{array}$ & $\begin{array}{c}\text { 14:21:13.1 } \\
\text { PM }\end{array}$ & $\begin{array}{c}\text { 15:04:31.2 } \\
\text { PM }\end{array}$ & $\begin{array}{c}15: 45: 31.2 \\
\text { PM }\end{array}$ \\
\hline B9 & $\begin{array}{c}\text { 13:11:12.6 } \\
\text { PM }\end{array}$ & $\begin{array}{c}\text { 13:58:22.7 } \\
\text { PM }\end{array}$ & $\begin{array}{c}\text { 14:37:38.2 } \\
\text { PM }\end{array}$ & $\begin{array}{c}\text { 15:22:56.1 } \\
\text { PM }\end{array}$ & B4 & $\begin{array}{c}\text { 13:42:05.4 } \\
\text { PM }\end{array}$ & $\begin{array}{c}\text { 14:22:18.6 } \\
\text { PM }\end{array}$ & $\begin{array}{c}\text { 15:05:12.5 } \\
\text { PM }\end{array}$ & $\begin{array}{c}\text { 15:46:14.6 } \\
\text { PM }\end{array}$ \\
\hline B10 & $\begin{array}{c}\text { 13:12:25.3 } \\
\text { PM }\end{array}$ & $\begin{array}{c}\text { 13:59:49.7 } \\
\text { PM }\end{array}$ & $\begin{array}{c}\text { 14:38:44.4 } \\
\text { PM }\end{array}$ & $\begin{array}{c}\text { 15:24:31.9 } \\
\text { PM }\end{array}$ & B3 & $\begin{array}{c}\text { 13:44:42.8 } \\
\text { PM }\end{array}$ & $\begin{array}{c}\text { 14:24:33.8 } \\
\text { PM }\end{array}$ & $\begin{array}{c}\text { 15:06:31.7 } \\
\text { PM }\end{array}$ & $\begin{array}{c}15: 47: 27.3 \\
\text { PM }\end{array}$ \\
\hline B11 & $\begin{array}{c}\text { 13:13:46.5 } \\
\text { PM }\end{array}$ & $\begin{array}{c}\text { 14:00:31.4 } \\
\text { PM }\end{array}$ & $\begin{array}{c}\text { 14:39:37.8 } \\
\text { PM }\end{array}$ & $\begin{array}{c}15: 25: 43.3 \\
\text { PM }\end{array}$ & B2 & $\begin{array}{c}\text { 13:47:34.5 } \\
\text { PM }\end{array}$ & $\begin{array}{c}\text { 14:26:40.8 } \\
\text { PM }\end{array}$ & $\begin{array}{c}\text { 15:07:49.5 } \\
\text { PM }\end{array}$ & $\begin{array}{c}\text { 15:48:39.6 } \\
\text { PM }\end{array}$ \\
\hline B12 & $\begin{array}{c}\text { 13:15:17.1 } \\
\text { PM }\end{array}$ & $\begin{array}{c}\text { 14:01:26.9 } \\
\text { PM }\end{array}$ & $\begin{array}{c}\text { 14:40:19.5 } \\
\text { PM }\end{array}$ & $\begin{array}{c}15: 26: 16.8 \\
\text { PM }\end{array}$ & B1 & $\begin{array}{c}\text { 13:48:01.6 } \\
\text { PM }\end{array}$ & $\begin{array}{c}\text { 14:26:51.2 } \\
\text { PM }\end{array}$ & $\begin{array}{c}\text { 15:09:16.7 } \\
\text { PM }\end{array}$ & $\begin{array}{c}\text { 15:50:03.2 } \\
\text { PM }\end{array}$ \\
\hline \multicolumn{6}{|c|}{ Total transport time } & $46: 29.3$ & $36: 52.4$ & $40: 36.2$ & $35: 22.6$ \\
\hline
\end{tabular}

${ }^{*} \mathrm{C}$ : Crushing head; ${ }^{*}$ L: Loading zone. 
Figure 6 shows the time and speed when the dump truck passed the major points of interest in the research area. The time and speed for each section were the average values of the four iterations of operation. Speed was calculated by dividing the distance between two consecutive sections by the amount of time taken. When comparing the time and speed of a truck along the route heading for the loading site as an empty vehicle with those along the route heading for the crushing head after loading the ore, we see that the time taken when the empty truck headed for the loading zone was shorter, since the empty truck could move faster than the loaded one.

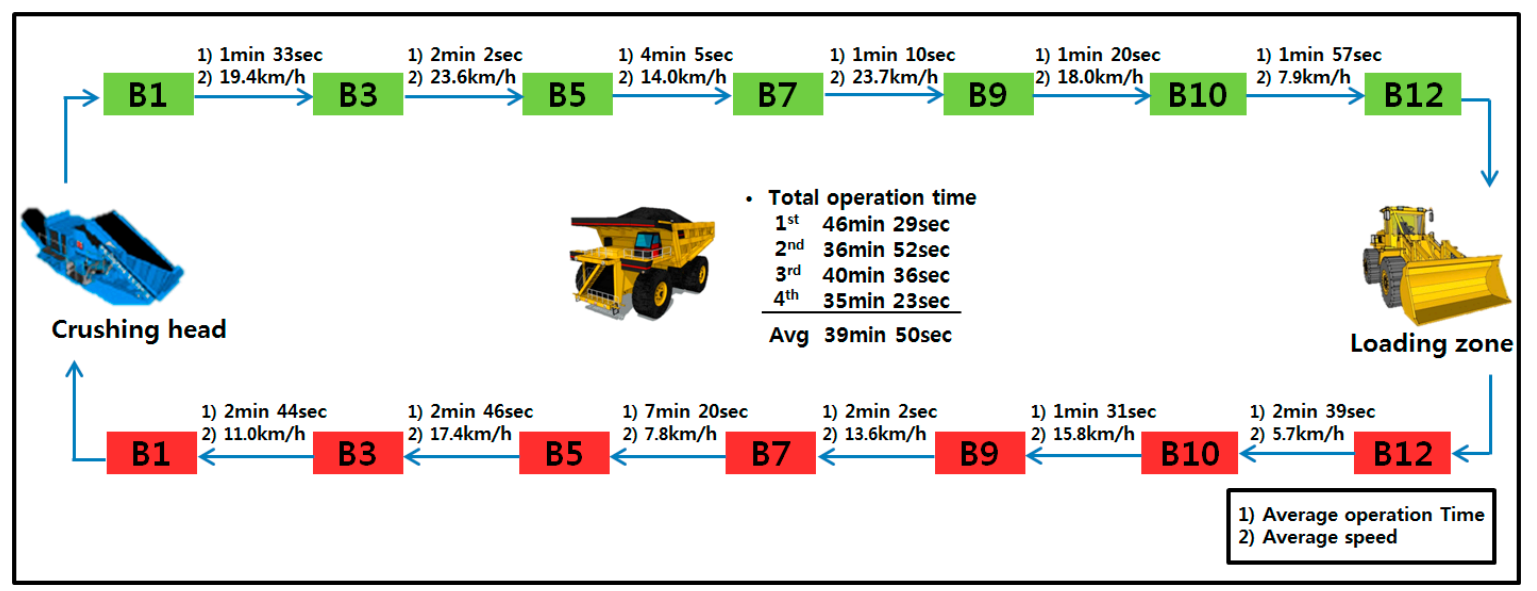

Figure 6. Analysis of transport time data collected by the Bluetooth beacon systems in the study area.

From the experimental results, we confirmed that the proposed method using a Bluetooth beacon system can measure the transport times of underground mining equipment without any fail in every trial. This means that the traditional time study method using a stopwatch can be replaced by the one presented in this study. The proposed method is effective in bringing the following remarkable advantages: (1) Collecting transport times of mine equipment in underground mines can be automated. (2) The accuracy of the measured transport time can be improved. Because most optimization techniques to solve problems in determining combinations, work orders, dispatching methods, and travel routes of mine equipment depend on transport times measured in mines, the proposed method enables mining engineers to generate mine production schedules of high quality. Therefore, it can contribute to improving the productivity of mine operation, especially for large underground mines.

\section{Conclusions}

This study measured the transport time of equipment used in underground mine sites by applying a Bluetooth beacon system. After installing Bluetooth beacons at the main locations of our study area and installing a smartphone that could recognize beacon signals in a 15-ton dump truck used in ore transportation, we quantitatively measured the transport time for dump trucks going back and forth between the loading point and the crushing head, and analyzed the time spent in each section of the conveyance area by calculating the time difference in beacon recognition. Through an on-the-spot inspection experiment, we proved that our method can measure transport time more conveniently and precisely than previous methods that used primitive means.

A Bluetooth beacon system has several advantages for use in underground mines. First, as shown in this study, it has outstanding signal detection and recognition capability. Therefore, it can be used in extreme environments, such as mines. Second, as smartphones can be used as beacon recognition terminals, it is possible to deploy the system in an easier and cheaper way than other wireless communication systems, which require expensive terminals and electronic/communication networks in mines. Third, as the Bluetooth beacon technology has low power consumption, it can be 
used for a few years on a coin battery without the need to install a power grid. Fourth, a Bluetooth beacon is made of plastic, is small in size, and highly durable. It is thus appropriate to use in extreme environments, such as underground mines with dust and humidity. Finally, since the Software Development Kit (SDK) of Bluetooth beacon products is generally available to the public, it is easy to develop application programs for it.

In this study, we chose the median values of the first and last beacon recognition times as the measured moving time of a dump truck. In the future work, it would be interesting to apply fingerprinting or positioning technology such as triangulation for more precise measurement of the transport times of underground mine equipment. In addition, a relatively straightforward extension of the current work includes the applications of a Bluetooth beacon system for (1) real-time location tracking, (2) automatic attendance tracking and (3) mine safety management systems.

Acknowledgments: This work was supported by (1) Korea Energy and Mineral Resources Engineering Program funded by the Ministry of Trade, Industry and Energy and (2) Basic Science Research Program through the National Research Foundation of Korea (NRF) funded by the Ministry of Education (2015R1D1A1A01061290). The authors thank anonymous reviewers for their critical comments and suggestions, which greatly improved the quality of our manuscript.

Author Contributions: Yosoon Choi conceived and designed the experiments; Jihoo Jung performed the experiments; Yosoon Choi analyzed the data and contributed reagents/materials/analysis tools; Jihoo Jung and Yosoon Choi wrote the paper.

Conflicts of Interest: The authors declare no conflict of interest.

\section{References}

1. Park, S.; Choi, Y.; Park, H.S. Optimization of truck-loader haulage systems in an underground mine using simulation methods. Geosyst. Eng. 2016, 19, 222-231. [CrossRef]

2. Baek, J.; Choi, Y.; Park, H.S. Uncertainty representation method for open pit optimization results due to variation in mineral prices. Minerals 2016, 6, 1-17. [CrossRef]

3. Berkhimer, E.N. Selection and sizing of excavating, loading, and hauling equipment. In SME Mining Engineering Handbook, 3rd ed.; Darling, P., Ed.; Society for Mining, Metallurgy \& Exploration (SME): Englewood, CO, USA, 2011; pp. 931-939.

4. Salama, A.; Nehring, M.; Greberg, J. Evaluation of the impact of commodity price change on mine plan of underground mining. Int. J. Min. Sci. Technol. 2015, 25, 375-382. [CrossRef]

5. Salama, A.; Nehring, M.; Greberg, J. Operating value optimization using simulation and mixed integer programming. Int. J. Min. Reclam. Environ. 2013, 28, 25-46. [CrossRef]

6. Nehring, M.; Topal, E.; Knights, P. Dynamic short term production scheduling and machine allocation in underground mining using mathematical programming. Min. Technol. 2010, 119, 212-220. [CrossRef]

7. Choi, Y.; Park, H.D.; Sunwoo, C.; Clarke, K.C. Multi-criteria evaluation and least-cost path analysis for optimal haulage routing of dump trucks in large scale open-pit mines. Int. J. Geogr. Inf. Sci. 2009, 23, 1541-1567. [CrossRef]

8. Choi, Y.; Nieto, A. Optimal haulage routing of off-road dump trucks in construction and mining sites using Google Earth and a modified least-cost path algorithm. Automat. Constr. 2011, 20, 982-997. [CrossRef]

9. Alarie, S.; Gamache, M. Overview of solution strategies used in truck dispatching systems for open pit mines. Int. J. Surf. Min. Reclam. Environ. 2002, 16, 55-76. [CrossRef]

10. Oraee, K.; Asi, B. Fuzzy model for truck allocation in surface mines. In Mine Planning and Equipment Selection; Hardygora, M., Paszkowska, G., Sikora, M., Eds.; Taylor \& Francis Group: London, UK, 2004; pp. 585-591.

11. Yan, S.; Lai, W. An optimal scheduling model for ready mixed concrete supply with overtime considerations. Autom. Constr. 2007, 16, 734-744. [CrossRef]

12. Ercelebi, S.G.; Bascetin, A. Optimization of shovel-truck system for surface mining. J. S. Afri. Inst. Min. Metall. 2009, 109, 433-439.

13. Salama, A.; Greberg, J. Optimization of truck-loader haulage system in an underground mine: A simulation approach using SimMine. In Proceedings of the 6th International Conference \& Exhibition on Mass Mining, Sudbury, ON, Canada, 10-14 June 2012. 
14. Saayman, P.; Craig, I.K.; Camisani-Calzolari, F.R. Optimisation of an autonomous vehicle dispatch system in an underground mine. J. S. Afri. Inst. Min. Metall. 2006, 106, 77-86.

15. Ta, C.H.; Kresta, J.V.; Forbes, J.F.; Marquez, H.J. A stochastic optimisation approach to mine truck allocation. Int. J. Min. Reclam. Environ. 2005, 19, 162-175. [CrossRef]

16. Beaulieu, M.; Gamache, M. An enumeration algorithm for solving the fleet management problem in underground mines. Comput. Oper. Res. 2006, 33, 1606-1624. [CrossRef]

17. Panagiotou, G.N. Discrete mine system simulation in Europe. Int. J. Min. Reclam. Environ. 1999, 13, 43-46. [CrossRef]

18. Jain, P.; Khanwlkar, S.S.; Malhotra, R.; Dheenrajappa, A.; Gupta, G.; Kobsa, A. uBeacon: Configuration-based beacon tracking. In Proceedings of the 2016 IEEE International Conference on Pervasive Computing and Communication Workshops (PerCom Workshops), Sydney, Australia, 14-18 March 2016.

19. Wang, Y.; Yang, Q.; Zhang, G.; Zhang, P. Indoor positioning system using Euclidean distance correction algorithm with Bluetooth low-energy beacon. In Proceedings of the Internet of Things and Applications (IOTA), Pune, India, 22-24 June 2016; pp. 243-247.

20. Ha, Y.U.; Jin, J.H.; Koo, H.S.; Lee, M.J. Exploration of BLE beacon application based on specification of beacon format and service. Adv. Sci. Technol. Lett. 2016, 129, 15-18.

21. Jin, J.H.; Lee, W.G.; Koo, H.S.; Lee, M.J. A service platform for rapid development of beacon-based applications. Int. J. Smart Home 2016, 10, 125-132. [CrossRef]

22. Bae, M.Y.; Cho, D.J. Design and implementation of automatic attendance check system using BLE beacon. Int. J. Multimed. Ubiquitous Eng. 2015, 10, 177-186. [CrossRef]

23. Yoon, C.P.; Hwang, C.G. Scheduling model for ready mixed concrete suppion-based service provider. J. Korea Inst. Inf. Commun. Eng. 2015, 19, 1368-1373. [CrossRef]

24. Google. Google Earth. Available online: http://www.google.com/earth (accessed on 3 October 2016).

(C) 2016 by the authors; licensee MDPI, Basel, Switzerland. This article is an open access article distributed under the terms and conditions of the Creative Commons Attribution (CC-BY) license (http:/ / creativecommons.org/licenses/by/4.0/). 